\title{
The Race of Mankind: Global Warming In the 21rst Century
}

\author{
Jan-Erik Lane \\ Public Policy Institute, Belgrade, Republika Srbija \\ E-mail: janeklane@gmail.com
}

Received: May 27, 2016 Accepted: June 13, 2016 Published: July 4, 2016

doi:10.5296/bmh.v4i2.9677～URL: http://dx.doi.org/10.5296/bmh.v4i2.9677

\begin{abstract}
The implementation process of the global accord on climate change has to start now in order to be implementable. The decentralized process if implementation should take the lessons from the theory of policy implementation into account (Pressman \& Wildavsky, 1984; Wildavsky, 1987). The dependency upon various forms of coal (wood, stone) and fossil fuels is so large in the Third World that only massive financial assistance from the First World can mean a difference for the COP21 objectives. And many advanced countries (except Uruguay) also need to make great changes to comply with COP21.
\end{abstract}

Keywords: COP21, Implementation, Superfund (Stern), Traditional and modern renewables, Fossil fuel dependency 


\section{Introduction}

Every day we can see the coming of a major risk to social and ecological systems by looking at the amount of CO2:s in the Earth's atmosphere (Earth's Co2 Home Page). It now stands at $\mathrm{mm} 409$, a sharp rise in the last years. Concomitant is the slow but ineluctable rise in global average temperature, where the temperature may actually by larger in certain regions, like the polar areas. As climate change could be highly detrimental to social and ecological systems on Planet Earth, the UN and governments of the countries of the world have finally counter-acted with: COP21 Agreement. The key question today is whether the COP21 can be implemented in such an effective manner that it halts and decreases this gigantic risk to mankind in particular and life in general. The purpose of this paper is to argue that a positive outcome of the COP21 is very doubtful.

\section{Means-End Efficiency}

In the policy sciences, an enquiry into the relationship between means and ends is most often of central interest, when examining governmental decisions, whether domestic or international ones. This relation is of a causal nature, the means either being conducive to the achievement of the goals, or not. Goal accomplishment consists of arriving at outcomes that fulfill the goals. This is one of classical models in the social sciences, emphasizing actions and their alternatives, probabilities or degree of effectiveness and outcomes or real life results. Some link with the methodological individualism of Max Weber, while others frame it more ambitiously in the rational choice with homo economicus. In any case, it is a most suitable model for evaluating policies or policy decisions, targeting the implementation of objectives.

The UN or UNFCCC and the world governments have arrived at a complex policy, referred to as the COP21. It is now up for decentralized implementation by the various national governments with an overview function for a special body of the UN. The stated means include:

a) Decreasing the CO2:s by 40 per cent until 2030

b) Moving towards a total decarbonisation of the economy and society in the second half of the 21rst century.

In policy-making, you often encounter so-called means-end chains: The ultimate objectives are to be accomplished by a set of means M1 and these M1 are in turn to be achieved by another set of means M2. In the COP21, the 40\% reduction and the total decarbonisation are to be promoted by the following means:

c) Elimination of energy sources that emit heavy CO2:s;

d) Replacement with new energy sources that are carbon neutral: solar, wind and geo-thermal power;

e) Financial assistance by means of a Stern like Superfund for helping Third World countries do c) and d) without much damage to their economies.

The idea is that projects c) and d) shall start 2020, although the exact form of the UN 
supervisory body and the superfund has yet to be decided, together with other oversight measures, like controls, evaluations, advice, in order to stem reneging. If some major car companies can cheat with emissions, why would not certain governments engage in opportunistic behavior with guile?

The causal theory implicit in this means-end chain with both M1 and M2 is that global warming is mainly the result of anthropogenic greenhouse gases, especially CO2:s, which in turn comes from economic activities around the world in a wide sense. Thus, the base model is the following:

(1) GDP is linked with energy consumption that is conducive to $\mathrm{CO} 2$ emissions, which model of causality we will enquire much into below.

One may examine the means in a policy in at least two ways. First, are the means recognized and intended really effective, meaning furthering the goals in question? Second, have all the relevant means been considered for the achievement of the objectives? Whereas we will concentrate upon the analysis of the first question below, we wish to strongly underline that the entire COP21 framework bypasses another very dangerous GHG, namely methane.

Methane makes up some $20 \%$ of the greenhouse gases. It is party anthropogenic, resulting for instance from agriculture (cows, pigs, and poultry), party natural, as pockets of methane are unlocked from frozen seabed or land sites, as a function climate change. If vast amounts of methane are released from the oceans or the tundra, the COP21 will definitely fail in halting global warming. As the implementation of the COP21 objectives moves ahead, much more attention has to be paid to the methane problematic, not only in agriculture.

\section{The Main Restriction: Economic Growth}

The means of $\mathrm{CO} 2$ reduction in the short run and total decarbonisation in the long run are to further the goal of halting climate change, given one major restriction. Global warming policy-making must not lead to economic decline, i.e., negative economic growth of the absence of economic development. Thus, the COP21 believes in the possibility of economic growth without emissions growth, breaking the pattern set for a long time (Figure 1).

LN

(Total GHG Emissions / Kg)

$\mathrm{CO} 2$ equivalent

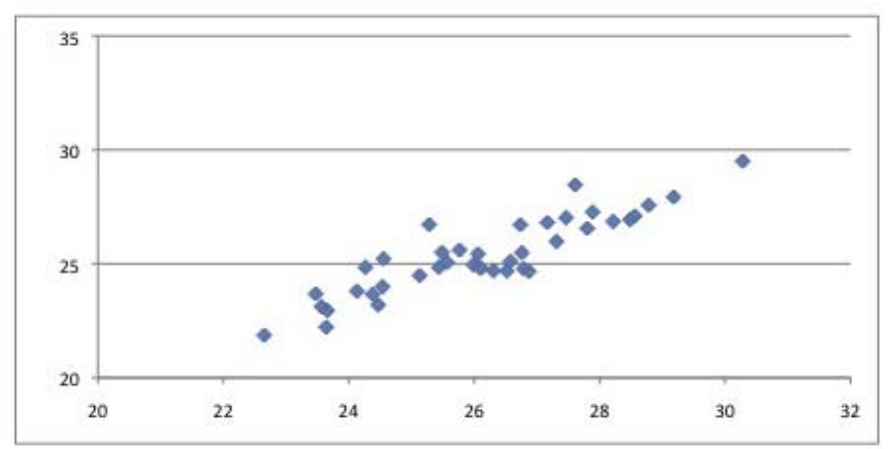

LN ( GDP / USD) (constant value 2005)

Figure 1. GDP-GHC Globally: $y=0.85 x, R 2=0.80$ 
Logically speaking, the CO2:s can only be reduced through decarbonisation of the economy in a wide, which can be promoted through:

- A zero growth economy or "sustainable economy", but it is not likely to occur, as this concept is opaque;

- A massive transition to solar, wind and nuclear power, which would require enormous new investments. Large scale solar and wind power needs huge space and are vulnerable to sabotage;

- $\quad$ A reduction in global output, meaning recessions. It will be avoided by governments by all means necessary;

- A global introduction of carbon sequestration technology, which is truly expensive.

The link between economic growth and environmental protection has been much debated in public policy and environmental economics. One may identify four positions:

- Positive: growth makes environmental protection feasible-rapid growth promotes environmental care;

- $\quad$ Negative: economic development uses up environmental resources or assets - zero growth economy;

- Contingency: it depends upon the particular project whether the impact is positive or negative;

- Trade-off: often development projects result in some economic gains against some environmental losses.

Examining the literature, one finds scholars advocating all four positions (Sachs, 2015). Probably one can find examples of all four types of combination between growth and environment in all countries: e.g., Indian solar panel parks, Chengdu Park for pandas, Jakarta harbour protection wall, opening up coal mines in tiger sanctuaries in India, burning down the rain forest in Kalimantan for agriculture, building the enormous dam-Three Gorges Dam in China, etc. But, as Indian expert Ramesh (2015) underlines, the question of emissions, energy and economic development involves somehow a trade-off between environment and growth. One may certainly fear that many governments will renege upon COP21, when faced with a choice between economic growth and green sustainability.

Interestingly, renowned economist Sachs has launched a coherent call for the world to move towards sustainable development, based on decarbonisation of the energy systems of countries (http://jeffsachs.org/2015/08/sustainable-development-for-humanitys-future/). He has correctly emphasized the close link between economic development or growth and the massive use of fossil fuels as energy sources during the last 20 years, resulting in the enormous expansion of GHG emissions in line with GDP. I believe it is more likely that global warming will simply proceed before people are willing to accept a sustainable economy, meaning total decarbonisation with loss of economic output, i.e., income. 


\section{The Intervening Variable: Energy}

When one enters energy into the debate about global warming and COP21, one understands the issues better. Economic growth in rich countries as well as economic development in poor countries needs a certain amount of energy input. Energy is the capacity to do work, meaning that energy sources crop up everywhere in society. Up until now, the most common form of energy source has been types of energy with carbon content. Logically, decarbonisation at $40 \%$ or $90-100 \%$ entails that this link is broken. Economic progress would be possible without carbon related energy sources and thus have carbon neutral emissions. Is this a figment of the hard core environmentalist's imagination, or practically achievable in a very short time span?

Energy consumption occurs in all sectors of the economy in a wide sense. And most of the anthropogenic CO2:s result from this energy consumption-see Figure 2.

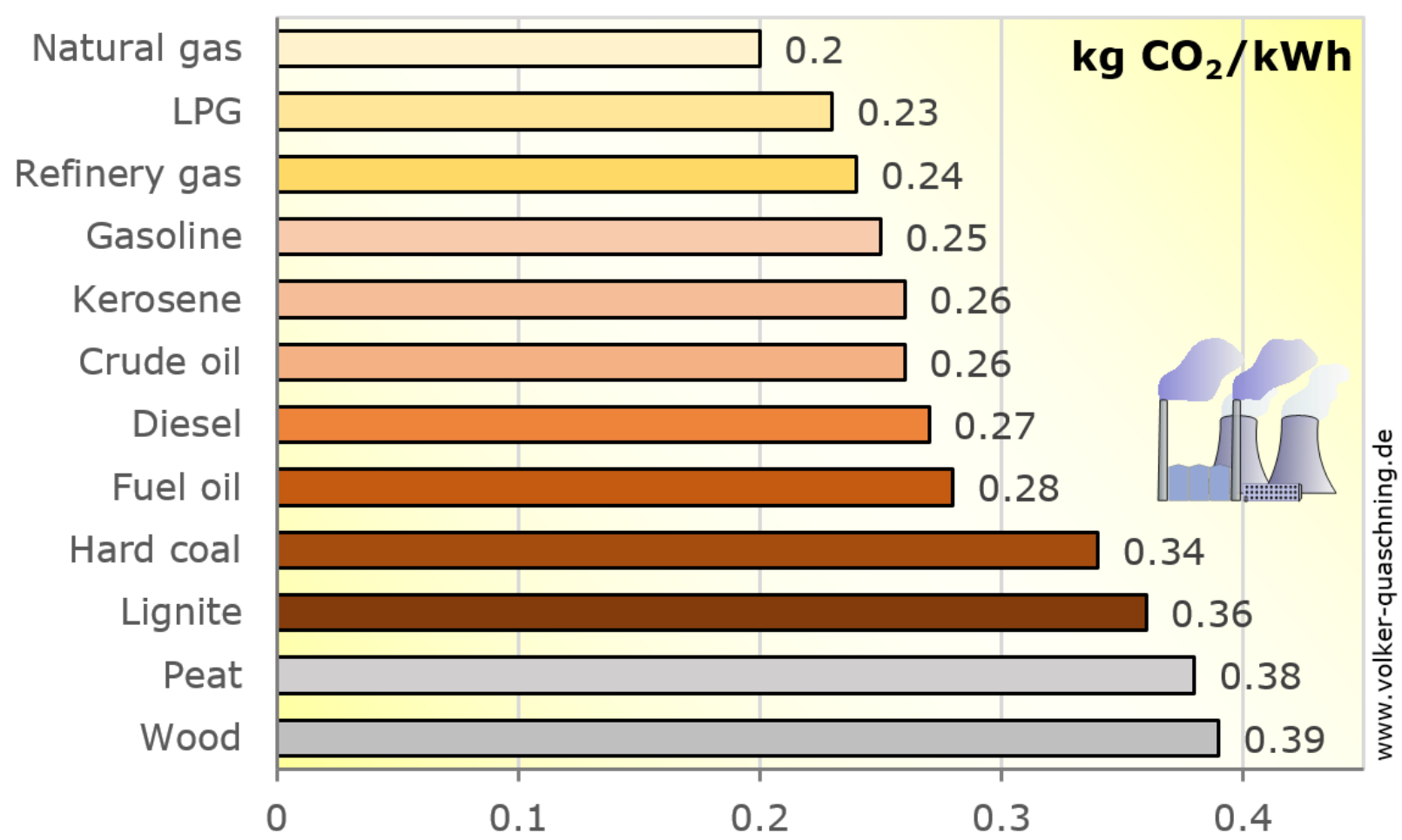

Figure 2. Specific carbon dioxide emissions of various fuels

Source: http://www.volker-quaschning.de/datserv/CO2-spez/index_e.php

Now, the COP21 process serves the purpose of decarbonisation, meaning decreasing country CO2 emissions, first by $40 \%$ until 2030 and later up to $90-100 \%$ by the end of this century. Whether a country can accomplish this depends upon two factors: its GDP-CO2 link and its actual energy mix. Note in Figure 2 that wood and charcoal is very harmful in terms of CO2.

The COP21 process will prove very demanding for any government and its society, both in the short-run and in the long-term perspective. As a matter of fact, a few continents are today 
experiencing fast population growth and rising demands for higher quality of life and public services. Of particular importance to ordinary people is the access to electricity. But electricity is often produced by burning the fossil fuels, resulting in CO2 emission. Now, the greenhouse gases must be reduced considerably, despite rising demands. How?

To understand the logic climate change policy-making in a country, one needs to know two essential things:

(2) <GDP-COP (GHG) link, Energy mix>

Where the first tells you how dependent the country economy is right now of emissions, and the second element informs you about the energy alternatives that are feasible for this country.

Generally speaking, one may wish to argue that:

- $\quad$ The closer the link between GDP and CO2 is positively, the more costly it will be to halt and reduce the rise in emissions;

- If this link is linear, then reductions in $\mathrm{CO} 2$ :s may come at the cost of recession or economic decline;

- The fewer the alternative energy sources are, the most costly will be the implementation of an energy policy resting upon renewables;

- Countries that are poor tend to rely heavily upon some of the fossil fuels and will require massive help from the superfund in the COP21;

- There is a blatant risk of reneging on the part of several countries, meaning the occurrence of implementation failure.

The concept of implementation failure was introduced into policy analysis and public administration by the late Wildavsky, underlining the profound distinction between policy and outcome, programs and results, as well as promises and reality (Pressman \& Wildavsky, 1973, 1984). Implementation being the process of carrying a policy into effect may fail, as the objectives stated do not surface in social life. Instead, polices may lead to irrelevant or even opposite outcome, when judges by the goals.

Successful implementation can only occur when a government has:

- Clear objectives

- $\quad$ Knowledge of the means

- Support from bureaucracy and society_-advocacy coalitions” with Paul Sabatier (1988, 1989).

I would like to state that decarbonisation policy-making does not fulfill these three essential and necessary requirements. Let me mention a few country examples where decarbonisation will prove difficult. 


\section{Mll Macrothink}

\section{Coal Dependency}

The largest emitter of CO2:s, China, has increased its emissions very strongly the last two decades, as an effect of its economic miracle-Figure 3. How is China going to meet the obligation to cut $40 \%$ of these enormous amounts of CO2:s?

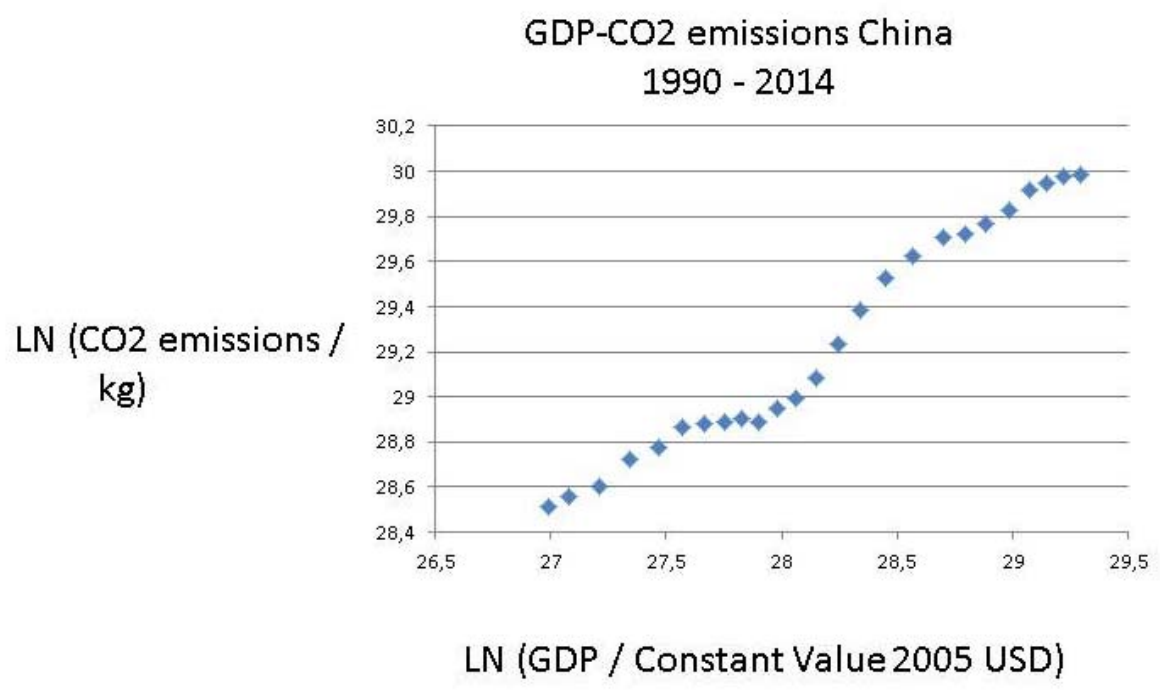

Figure 3. China: GDP-CO2:y $=0.70 x, R^{2}=0.97$

Chinese energy policy must of course start from the actual situation with regard to its energy mix. It relies heavily upon fossil fuels, especially coal-Figure 4.

\section{China energy consumption 2014}

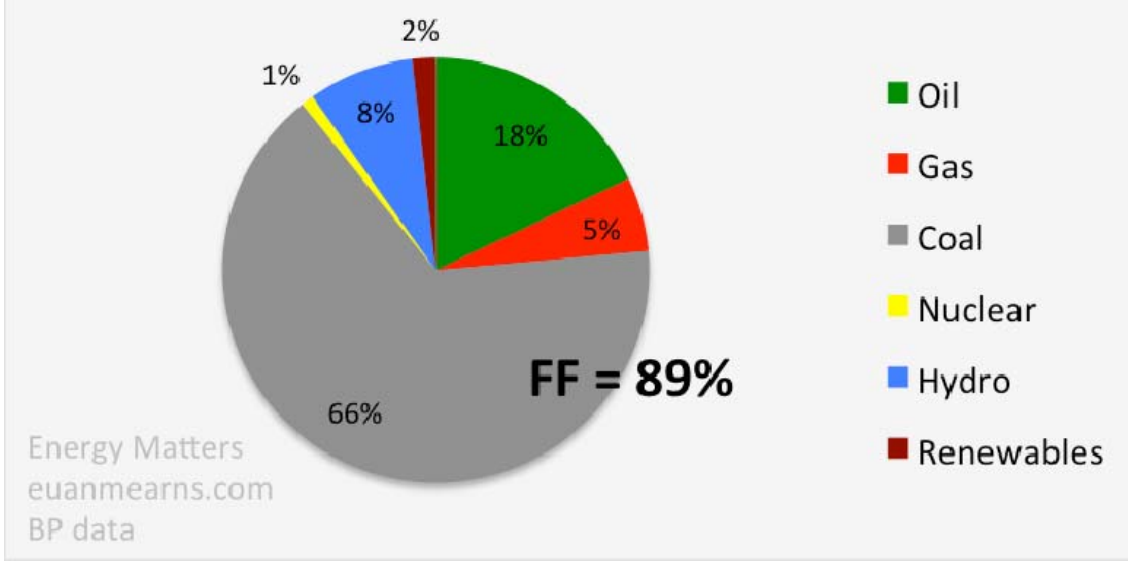

Figure 4. China’s energy mix 


\section{Macrothink}

It is true that China's leaders have understood that the energy mix above is completely sustainable. Thus, a frenetic activity has been initiated to increase modern renewables: solar, wind and hydro power besides massive investments in atomic power. Old coal mines have been shut down. Yet, does all of this add up to diminish the CO2:s? Perhaps halting the increase in CO2:s, but hardly a decrease of 40\%, as required by 2030 .

China cannot allow economic growth to go down towards zero, meaning that it must find new energy sources that are carbon neutral to continue its magic economic advances. China may wish to invest in carbon capture and sequestration, or even venture into carbon sucking projects. The new energy policies will be costly for China!

It should be pointed out that transparency is lacking about the real outcomes of China's new ambitions. If many coal mines are in fact shut down, then how many new ones are opened or planned? Sometime, China says its ambition to halt or decrease CO2:s are relative (to GDP) and not in absolute numbers. This would make all talk about COP21 implementation ambiguous or opaque.

A nation relying almost exclusive upon coal is South Africa. Its energy mix appears in Figure 5 .

Total Primary Energy Supply in South Africa 2012 [\% TPES]

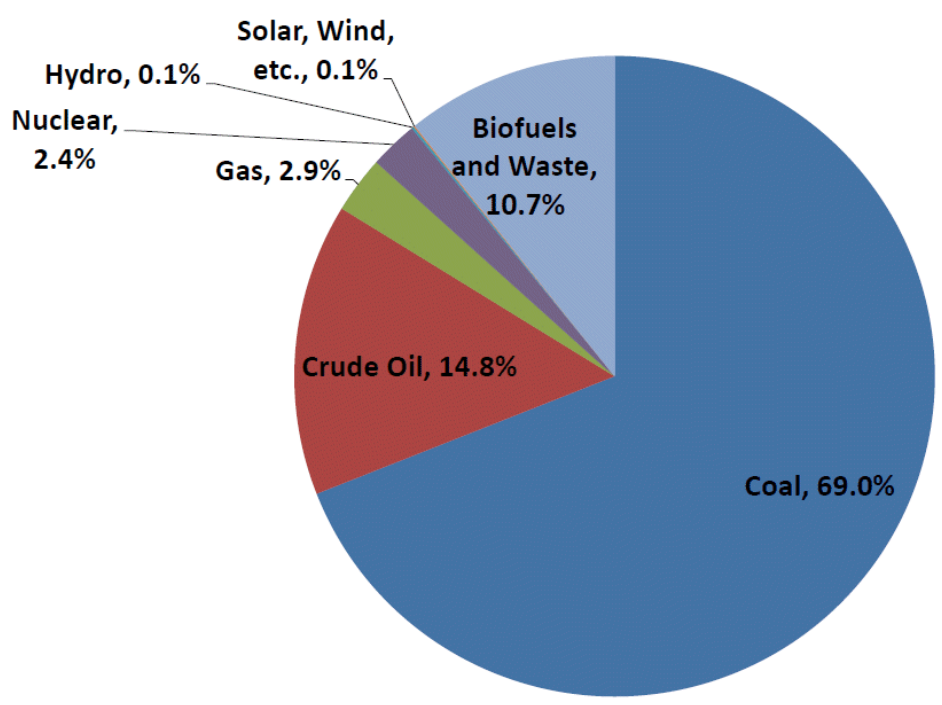

Figure 5. RSA: Energy mix

One may suspect that biomass as almost always on the African continent include lots of charcoal and dung, which brings the coal dependency over 70\%. Modern renewables are employed much too little to let South Africa comply with the COP21. Although the country is plentiful of coal, it must turn towards solar energy, which also would come plentiful. 


\section{Oil and Gas Dependency}

When countries are heavily dependent upon fossil fuels, it may actually not be coal that is the largest source, but oil and gas. To verify this, we go to the north of Africa, the Maghreb.

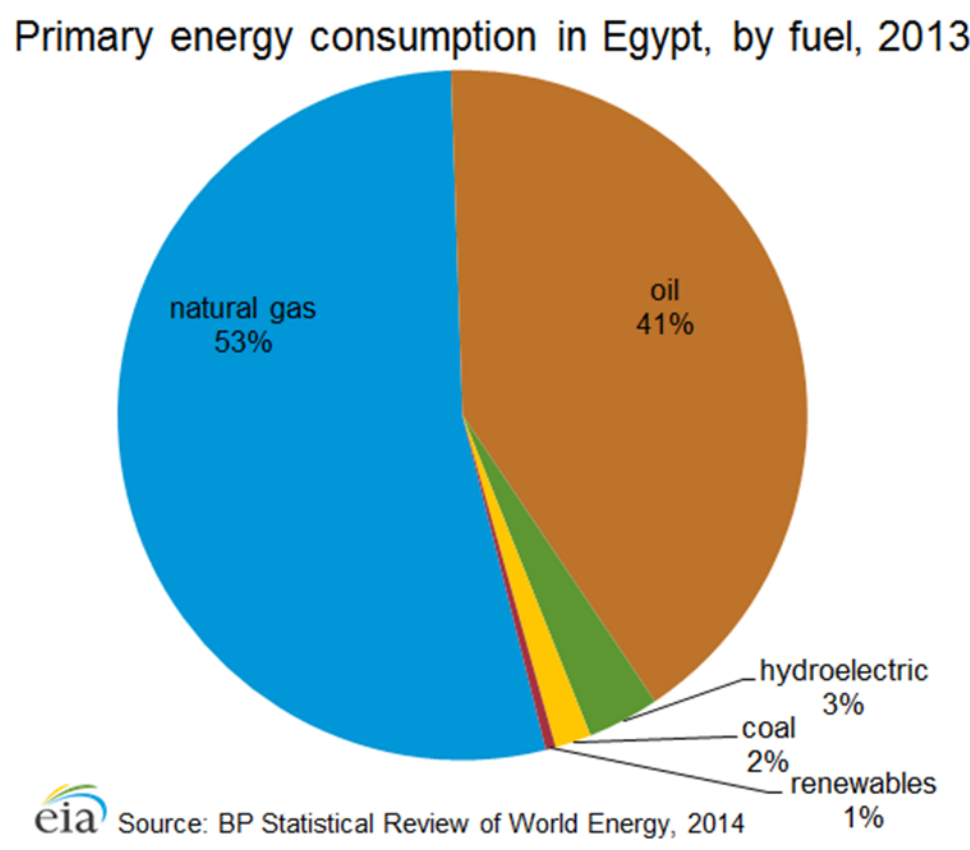

Figure 6. Egypt: Energy mix

Figure 6 presents an entirely different energy picture than the RSA. Egypt with its giant population has not been able to employ hydro power as much as one would be inclined to presume. The Nile Valley countries find it very difficult to reach an agreement about how to use and divide these enormous water masses. As for the RSA, CO2 increases follow the GDP.

Oil producing countries tend to rely exclusively upon petrol and gas. Here, we offer Mexico and Saudi Arabia as examples. 
Total energy consumption in Mexico by type, 2014

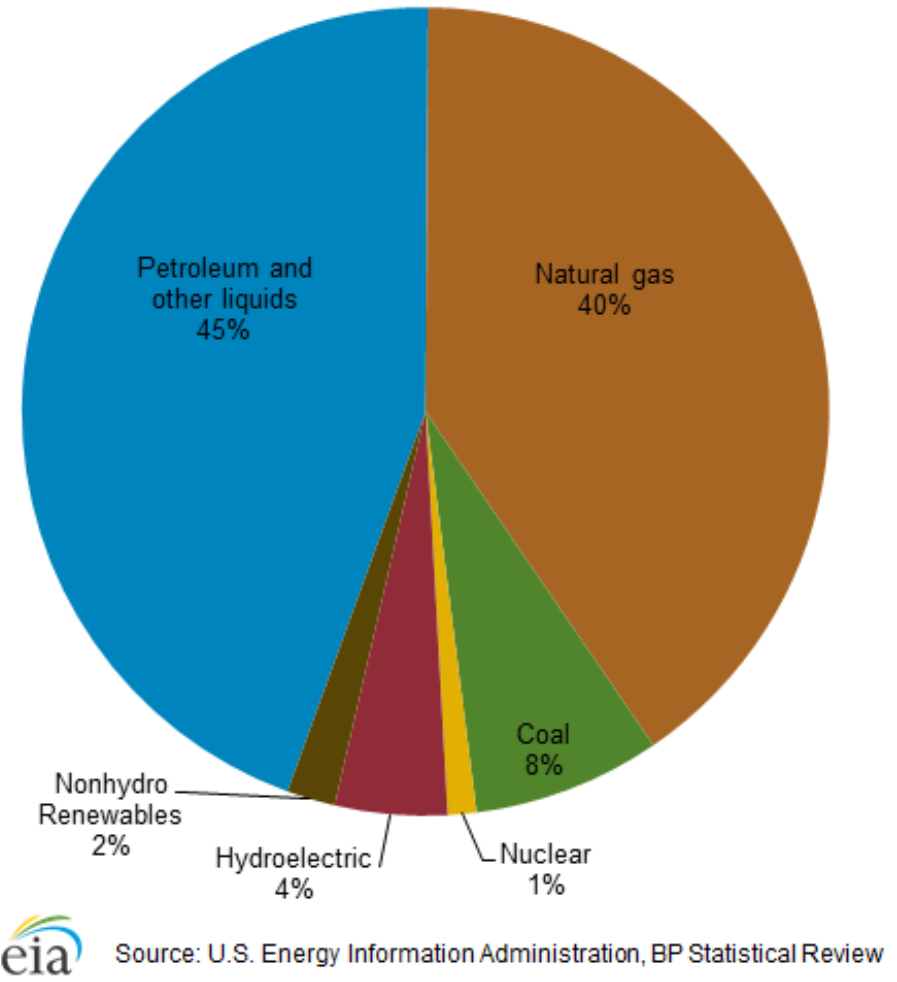

Figure 7. Mexico: Energy mix

With this pattern of energy consumption, Mexico is the largest emitter of CO2 with Brazil in Latin America. Comply with COP21, it has to reduce oil and gas, moving towards solar power and perhaps atomic power.

In the Gulf, the reliance upon fossil fuels oil and gas is 100\%. CO2 emissions are quite substantial, or on a per capita basis the biggest world-wide. 


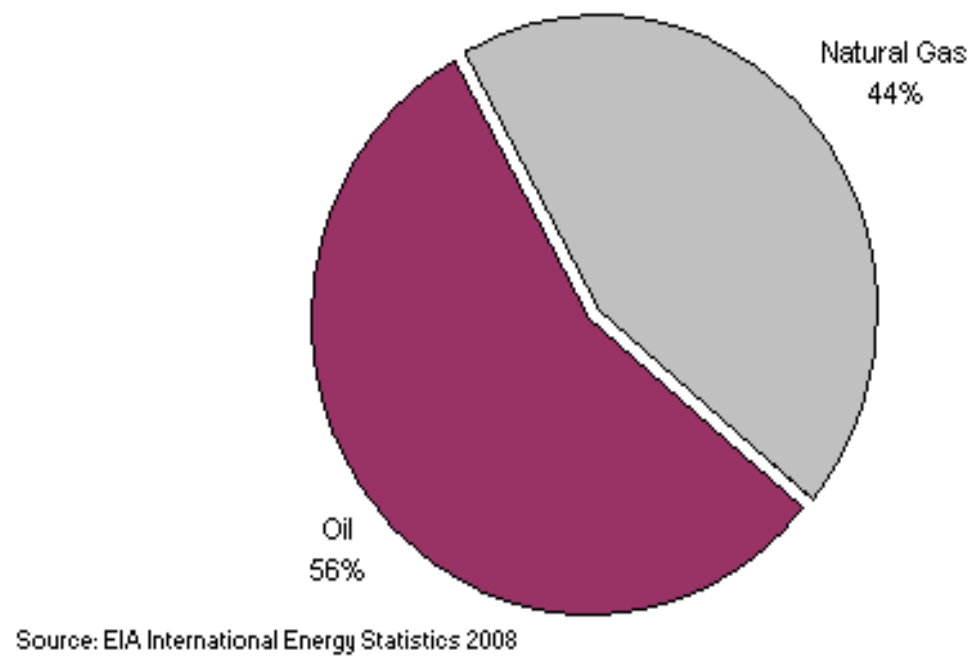

Figure 8. Total energy consumption in Saudi Arabia, by Type (2008)

The Gulf states employ fossil fuels for generating electricity for their conspicuous consumption, paranoiac building projects (cement) and maintaining high standards in transportation. Some of them have started to invest in nuclear power and modern renewables so that they can sell oil and gas on the world markets. The advanced Gulf States are also introducing solar power, but the scale of these renewable energy experiments does not much reduce their fossil fuel dependency. Iran displays the same energy mix, and they eagerly want access to market to sell oil and gas, to be replaced with atomic power, hopefully.

\section{Dependency on Traditional Renewables}

A general teent in the climate change debate is that renewables should be preferred over non-renewables. Yet, this statement must be strictly modified, as there are two fundamentally different renewables:

- Traditional renewables: wood, charcoal and dung. They are not carbon neutral. On the contrary, employing these renewables results in severe pollution, not only outside but also insidea household;

- $\quad$ New renewables: solar, wind, geo-thermal and wave energy that are indeed carbon neutral, at least at the stage of functioning.

In the poor African countries with about half the population in agriculture and small villages, traditional renewables constitute the major source of energy. 


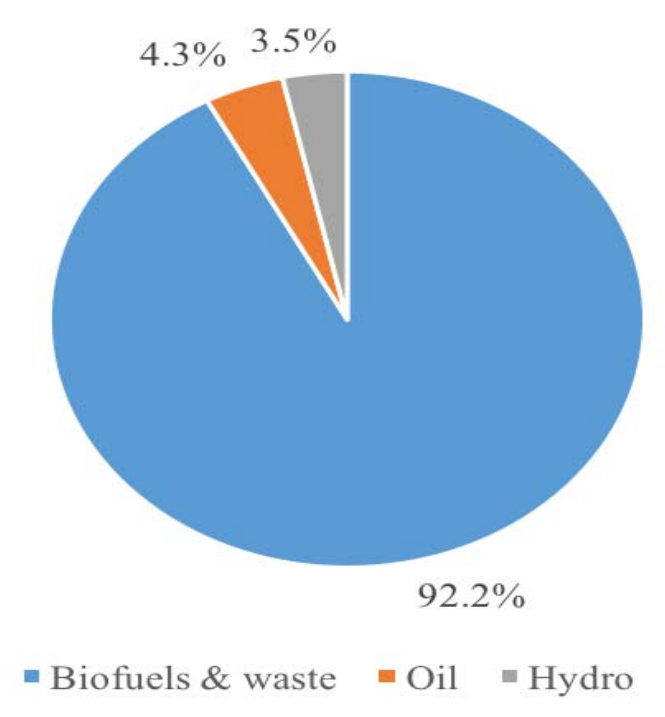

Figure 9. Dr Kongo

Source: Democratic Republic of Congo-Energy Outlook, Kungliga Tekniska Hoskolan

One notes how little of hydro power has been turned into electricity in Kongo, but economic development and political instability, civil war and anarchy do not go together normally. At the same, one may argue that an extensive build-up of hydro power stations would pose a severe challenge to the fragile environment in the centre of Africa. Kongo can now move directly to modern renewabes like solar power.

The energy consumption of Sudan reflects this situation-Figure 10. The countries that rely upon traditional renewables to an extent upto 50 per cent or higher will have to reflec upon how to bring these figures with modern renewables. Iit is an entirely different task than that of countriess with too much fossil fuel dependency.

Sudan is dismally poor with deep-seated internal conflicts ethnically. How to move to large solar panel plats in a country with so much political innstabilyi resulting huge numbers of death from domestic violence? 


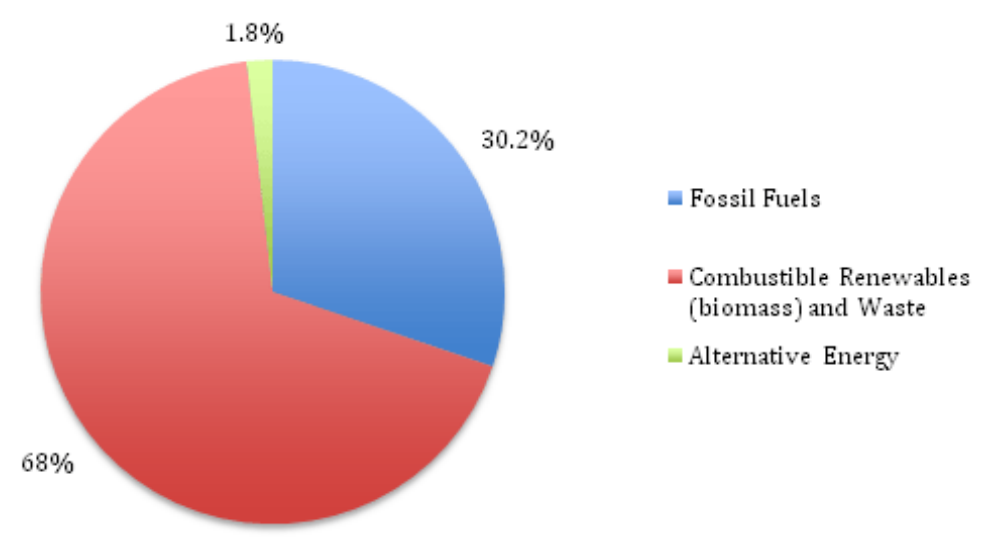

Figure 10. Sudan's energy consumption

Source: http://500wordsmag.com/science-and-technology/the-case-of-photovoltaics-in-sudan/

The reliance upon traditonal renewables is so high in neighbouring Ethiopia that electrification must be very difficult to accomplish over the large land area. Figure 11 displays a unique predicament.

\section{SHARE OF ETHIOPIA'S ENERGY SUPPLY 2008 (IN\%)}

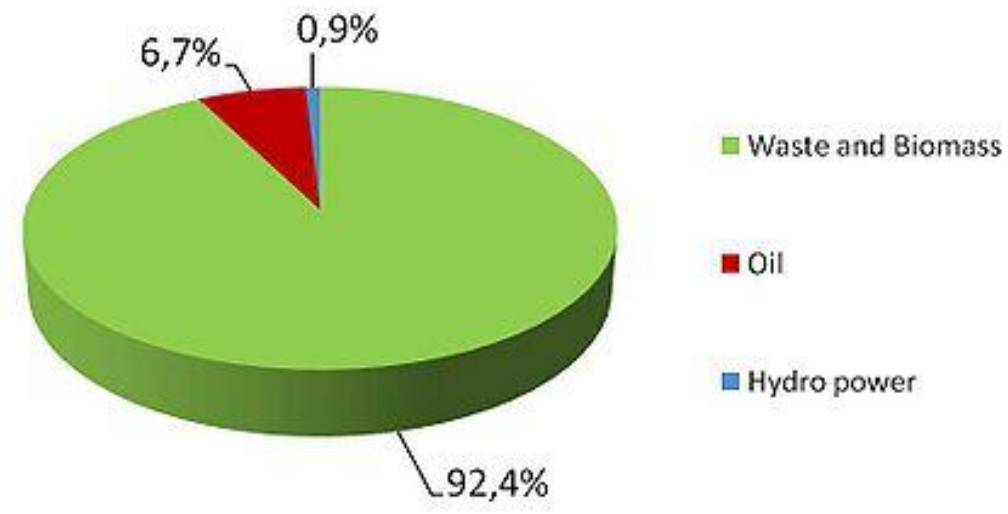

IEA 2008

Figure 11. Ethiopia: Energy mix

Is there any advantages with such a skewed energy mix? No, becausee even mainly rural Ethiopia works with lots of CO2: see Figure 12. 


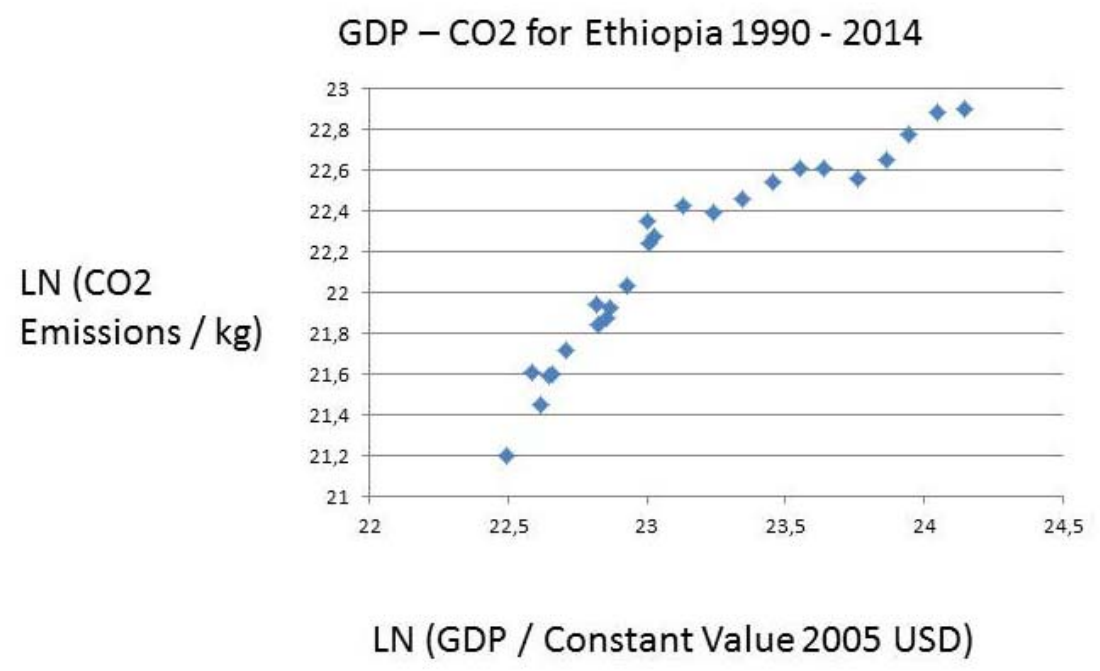

Figure 12. Ethiopia: GDP and CO2: $y=0.90 x, R^{2}=0.88$

The zest with which Ethiopia is pursuing its control over water resources becocomes flly understandable, when Figure 12 is consulted. Whar we aee is the same smooth linear function plotting CO2:s upon GDP, as is obvious in countries based upon fossil fuels-see below. For Ethiopia, to comple with COP21 goals is goint to pose major challenges, especially if economic development is not going to be reduced. The country needs massive help, both finacially ad technologically.

\section{Demand for Electrification}

The global agreement on cutting down $\mathrm{CO} 2$ emissions comes at a point in time when several nations hope for the first time to offer the convenience of electric power to all its citizens. If a country possesses much coal, then burning it gives much electricity in a cheap manner. But the COP21 commitment eliminates this alternative. Look at India in Figure 13 with enormous CO2 emissions. 


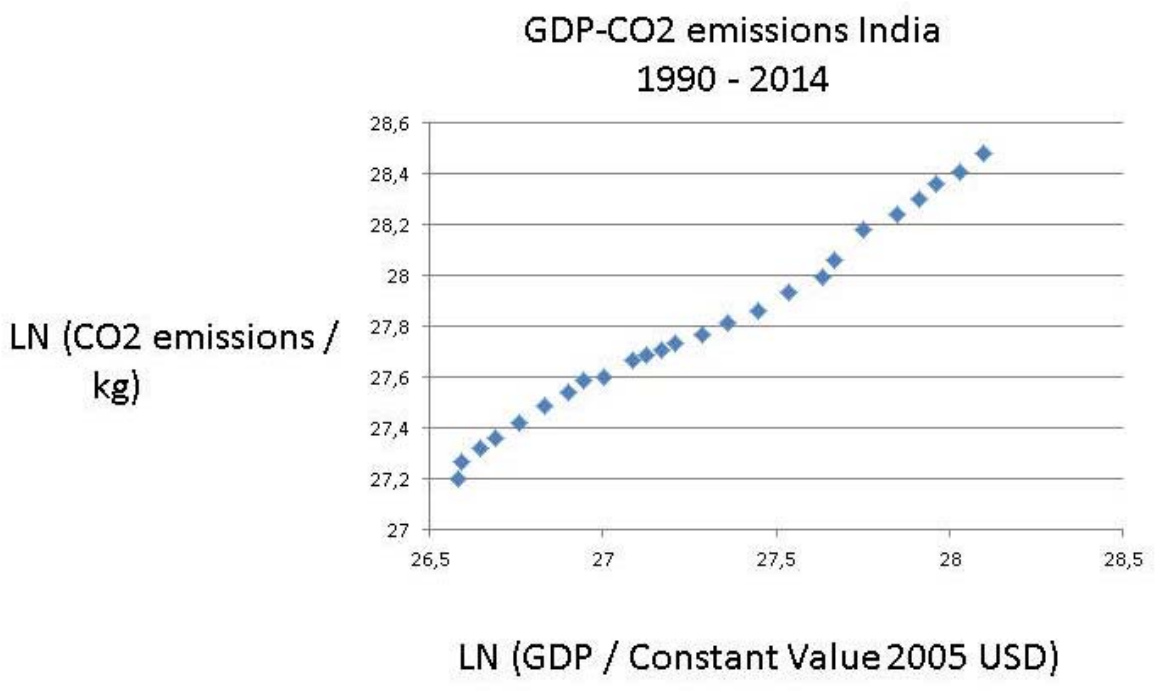

Figure 13. India: GDP-CO2: $y=0.7702 x+6.79 ; \mathrm{R}^{2}=0.99$

India needs cheap energy for its industries, transportation, housing and heating as well as much more electrification. From where will it come? India has water power and nuclear energy, but relies most upon coal, oil and gas as power source. It has strong ambitions for the future expansion of energy, but how is it to be generated, the world asks. India actually has one of smallest numbers for energy per capita, although it produces much energy totally.

Growth-ecology trade-off

Ramesh (2015) is a remarkable Indian publication, comprising more official documents than written own analysis. Author Ramesh has published documents from his period as Minister of Environment in the federal government, where we find all sorts of materials: speeches, public letters, administrative decisions, etc. This means that the Reader has to work hard with texts, as the short comments by the Author are rather general in tone. However, this is interesting and highly relevant reading.

Ramesh has a long experience with the so-called Great Green Growth Gamble from acting in several roles, academically and politically. Highly relevant for understanding the conditions for ecological policy-making in the largest country in the world very soon ate the materials concerning the following themes;

1) India’s coal dependency

2) The immense need for electricity

3) The implementation gap of environmental legislation and decrees

4) The clash between economic growth and environmental protection

6) India' large vulnerability ecologically to global warming and environmental degradation

7) The drying up of rivers for hydro generation and the loss of land to sea level rise. 


\section{Macrothink}

Interestingly, Ramesh emerged from the growth lobby but turned ecologically friendly when faces with all the demands for clearances for ecological interference. No wonder he was controversial as minister, considered both growth advocate and the NO GO man. He is well entrenched in the global discussions concerning climate change policy-making, claiming that India has a major contribution to render in the debate about the necessary growth-ecology trade off.
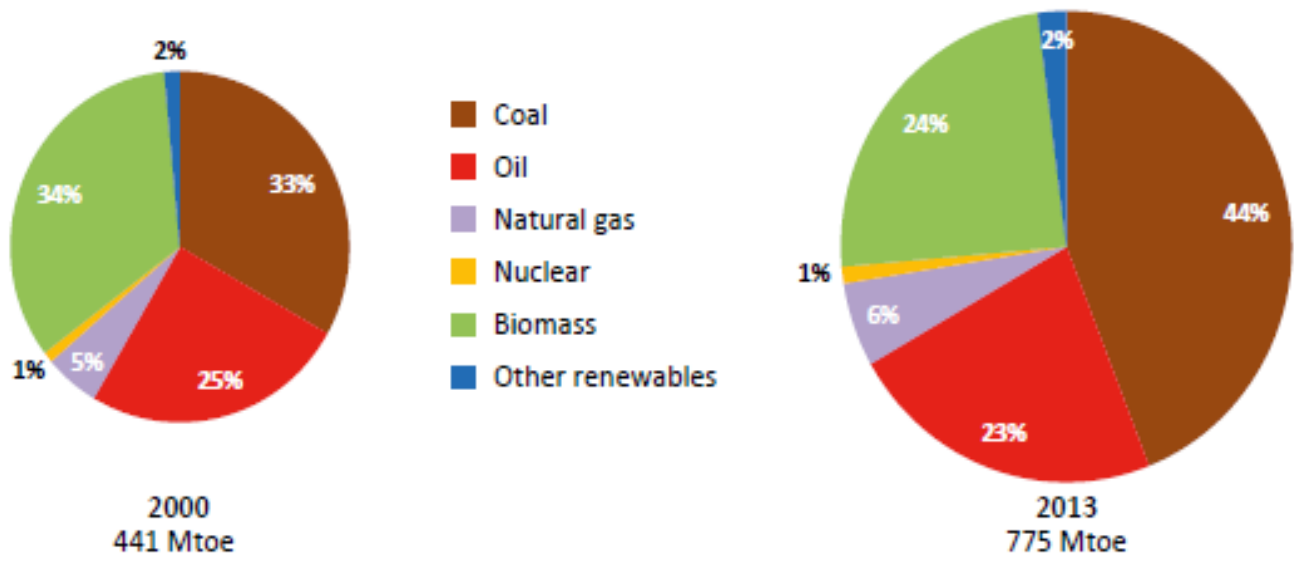

Figure 14. India’s energy mix

India needs especially electricity, as 300 million inhabitants lack access to it. The country is heavily dependent upon fossil fuels (70 per cent), although to a less extent than China. Electricity can be generated by hydro power and nuclear power, both of which India employs. Yet, global warming reduces the capacity of hydro power and nuclear power meets with political resistance. Interestingly, India uses much biomass-wood, charcoal and dung-as well as waste for electricity production, which does not always reduce GHG emissions - quite the contrary actually. India's energy policy will be closely watched by other governments and NGO:s after 2018. And the country needs massive financial support from Stern's fund in order start using modern renewables and atomic power.

\section{Dependency on Water Power}

Water is a powerful source of energy, though not comparable to atomic power of course. It is absolutely carbon free, except in construction. It may or may not damage the environment, but it adds crucially to country independence from international oil and gas markets. Look at Latin America where water from the Andes is plentiful. 


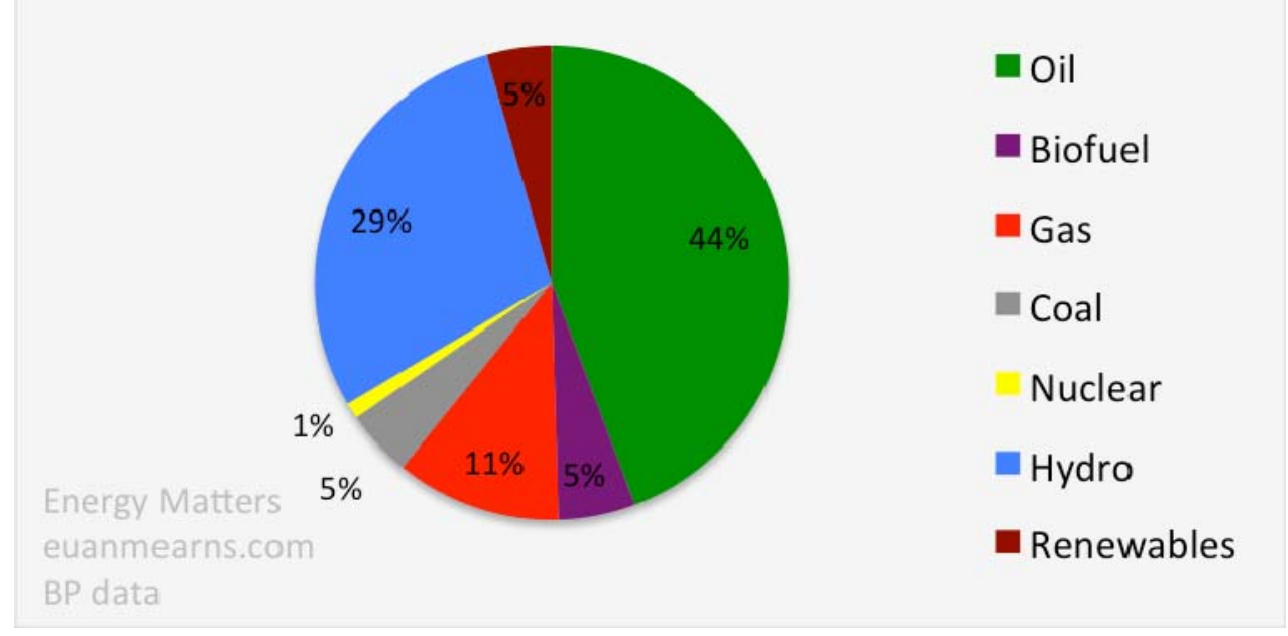

Figure 15. Brazil: Energy mix

Hydroelectric power is massive in Brazil and capacity has grown steadily since 1965. However, hydro production has been down owing to late and light rains. Brazil is one of the few countries in the world where liquid biofuel production is significant: ethanol. Gas production in Brazil is significant, but Brazil has very little of coal production. In 2006, the discovery of vast oil resources in the sub-salt strata of the Santos Basin promised petroleum bonanza, but deep water and sub-salt setting has posed technical challenges and high costs. Brazil has 3 nuclear reactors, but nuclear provides merely 1\% of primary energy.

One can hardly say that it will easy for Brazil to live up to its COP21 commitments, despite its comparatively low dependence upon fossil fuels. Its large hydro power supply is vulnerable to draught, as rivers dry up. And then one must add the political difficulties in managing the oil and gas reserves properly in giant enterprise Petrobas. The huge Mato Grosso could be used for renewable energy generation, wind and solar power.

Energy is an interesting aspect of this nation, which is now in turmois because of the lack of it, despite the immense oil and gas resources of this country. Just as with otheroil producing countries, one expects the CO2:s to be quite substantial. Figure 16 confirms thiss expectation, but one may note many yearly ups and downs in reWhy this link is not a smooth one may be explained both by the energy mix and the volatile politics of Venezuela. 
GDP - CO2 for Venezuela 1990 - 2014

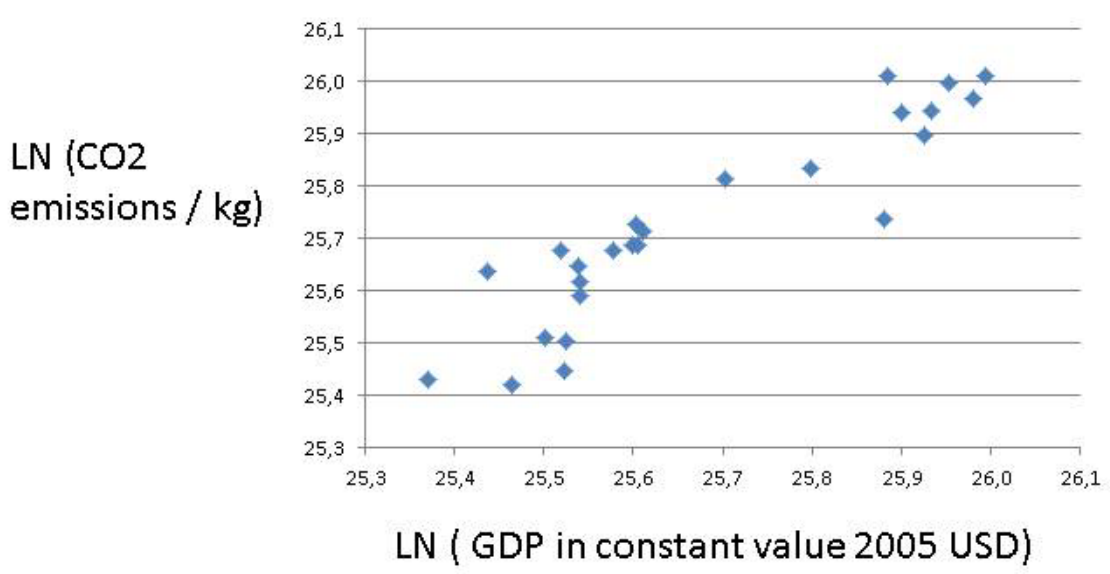

Figure 16. Venezuela: GDP-CO2: $\mathrm{y}=0.87 \mathrm{x} ; \mathrm{R}^{2}=0.85$

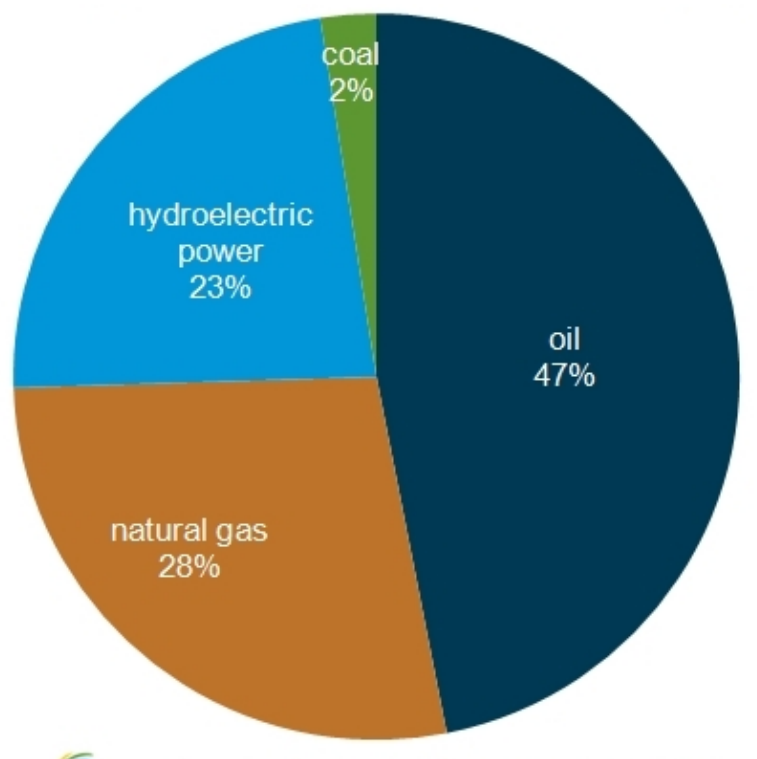

eia Source: U.S. Energy Information Administration

Figure 17. Venezuela: Energy mix

The dependency upon fossil fuels is high in Venezuela, but the country differens from Mexico in that it disposes of considerable hydro power. Typical of Latin America is that several countries make use of hydro power to mitigate their dependency upon fossil fuels, mainly oil and natural gas. In the case of Venezuela, it is the water resources that have failed, causing enormous electricity chaos, resulting in huge loss of output and work. Evidently, no Venezuelan government has not taken precautionary action, building for instance some sets of back up generators based upon its massive oil and gas reserves. 


\section{Macrothink}

Business and Management Horizons

ISSN 2326-0297

2016, Vol. 4, No. 2

\section{Dependency on Nuclear Power}

Interestingly, also France has like Germany managed decarbonisation to some extent (Figure 18). It reflects its unique energy mix, relying much upon nuclear power in a comparatively unique way.

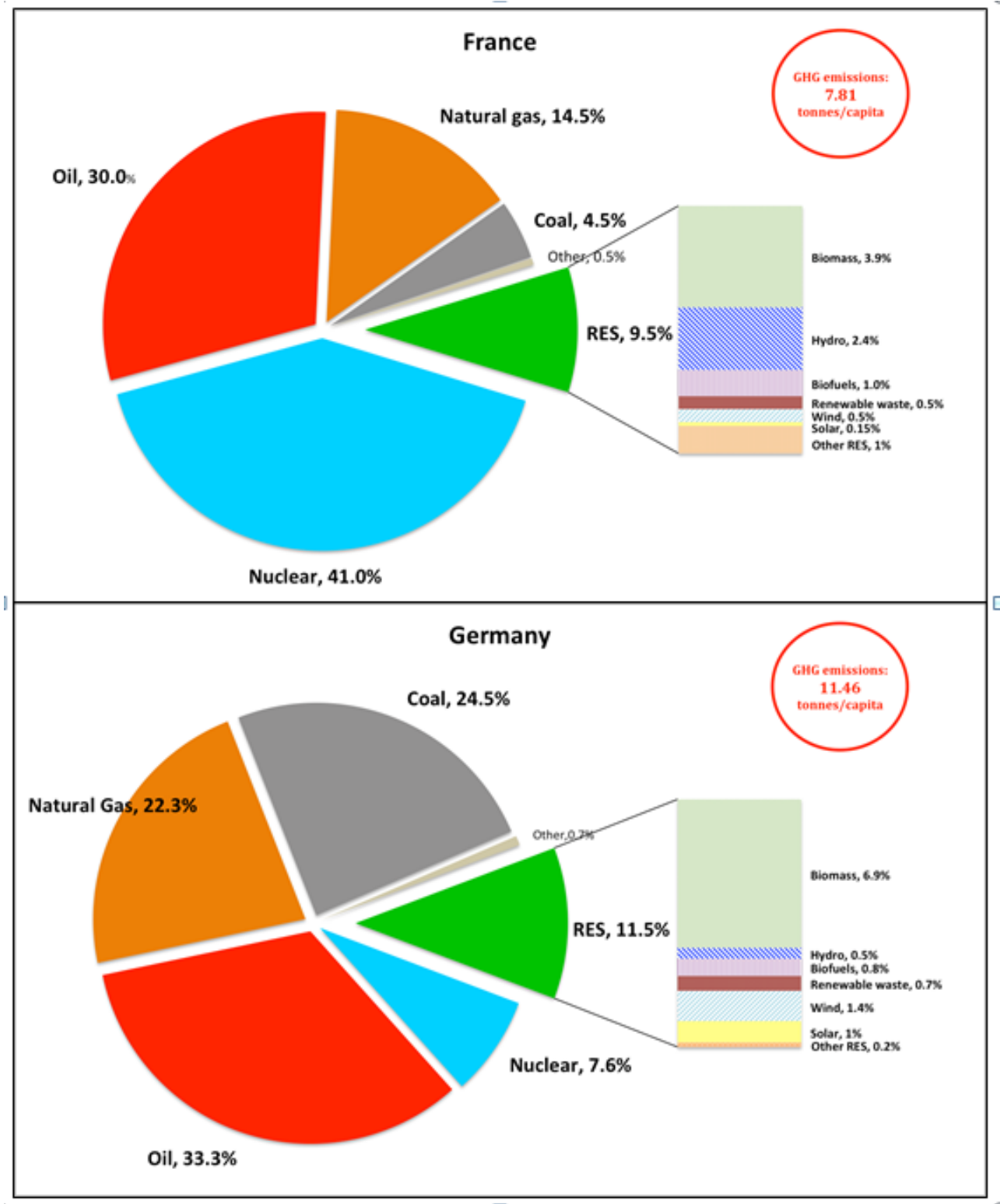

Figure 18. France and Germany’s total primary energy consumption per source (2013) and GHG emissions per capita (2012)

Source: http://blog.iass-potsdam.de/2015/05/energy-transition-france-following-in-germanys-footsteps/

Yet, France has decided to diminish its reliance upon nuclear power. But how will it be replaced by other sources of energy? Figure 18 infroms about the considerable reliance upon fossil fuels in Germany and France too. France and a few other countries deviate from the 
global patters, as the curve for GDP-CO2 is sloping somewhat down recently (Figure 19).

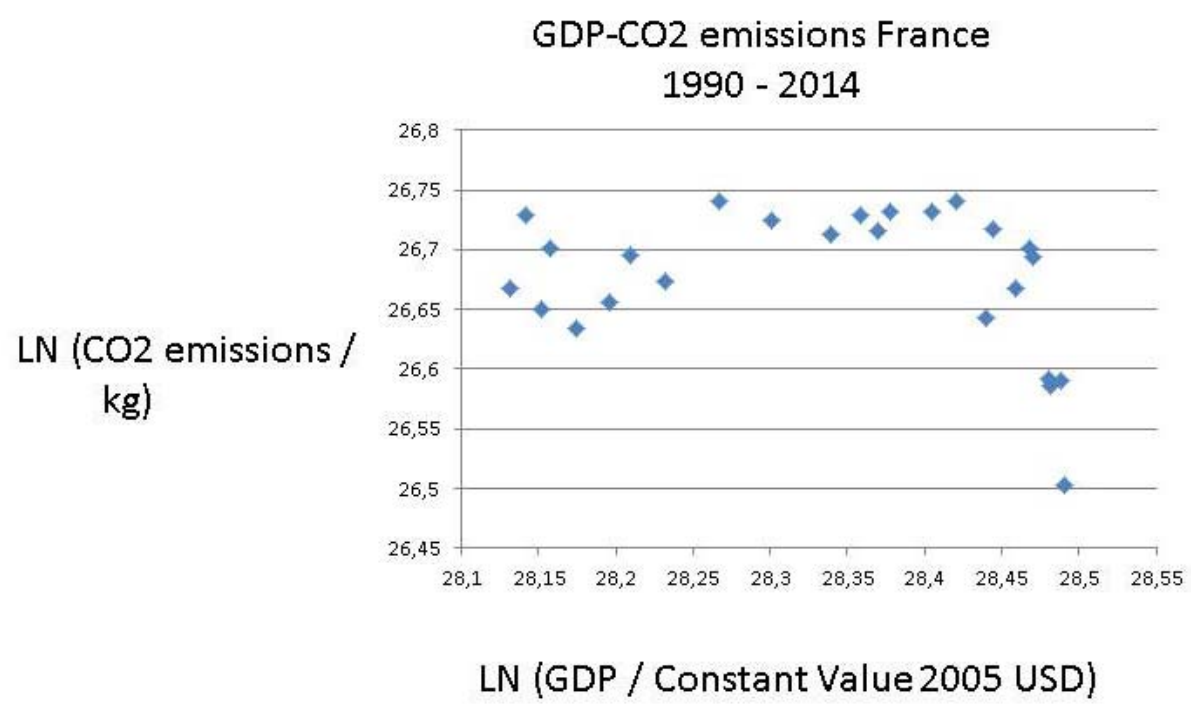

Figure 19. France $\left(y=-0.13 x+30.4 ; R^{2}=0.08\right)$

As underlined, no other country in the world employs nuclear power to such an extent, allowing France to avoid lost of CO2:s (Figure 19). But the Green movement's criticism of nuclear power is based upon entirely different argument than the wish to decarbonise economy and society. Actually, doing both-decarbonisation and de-nuclearisation-may prove difficult for France. The French energy sector-EDF and AREVA-has sufferedimmensely from lower energy prices and scepticism about nuclear power, requiring massive state support. Perhaps the European Green Movement cannot have it both ways: shutting down nuclear power and elimination fossil fuels?

\section{Conclusion}

Scholars who argue that we can have both decarbonisation and economic growth bet upon the arrival of both more energy efficient technologies and technological innovations that lead to more energy but have little emissions of greenhouse gases. Thus, nuclear power plants can be built in such a way that the risk of a melt-down is excluded. And solar power gets all the time cheaper and more reliable.

Yet, in relation to the COP21 Agreement there is cause for much pessimism. It is true that small changes are feasible, replacing fossil fuels with renewables, but we are talking about the need for large scale transformation. See a standard prediction for energy demand in Figure 20. 


\section{Industrialisation and growing power demand...}

By region $\quad$ By primary use $\quad$ By fuel

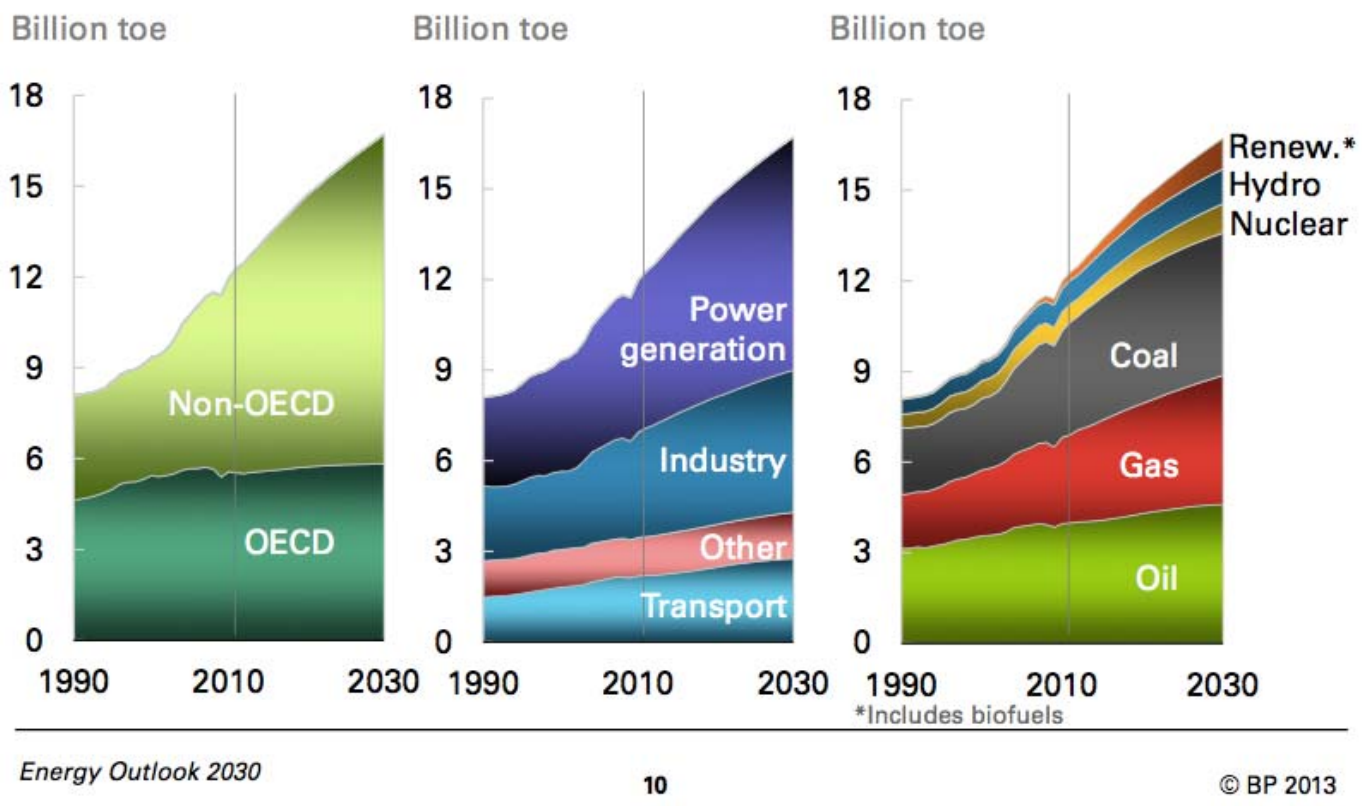

Figure 20. Stylised energy projections

Source: https://therationalpessimist.com/tag/bp-energy-outlook-2030/

These projections for 2030, the year of COP21, are completely outside of its objectives of a $40 \%$ reduction of $\mathrm{CO} 2$ emissions.

The CO2:s can only be reduced through decarbonisation of the economy in a wide, which can be promoted through:

- A zero growth economy or "sustainable economy" with Sachs, but it is not likely to occur;

- A massive transition to solar, wind and nuclear power, which would require enormous new investments. Large scale solar and wind power needs huge space and are vulnerable to sabotage;

- A reduction in global output, meaning recessions. It will be avoided by governments by all means necessary.

\section{References}

BP Energy Outlook 2016.

Energy Information Administration. Washington, DC.

EU Joint Research Centre Emission Database for Global Atmospheric Research. [Online] 
Available: http://edgar.jrc.ec.europa.eu/overview.php

International Energy Agency. Paris.

Pressman, J., \& Wildavsky, A. (1973, 1984). Implementation. Berkeley: University of Cal Press.

Ramesh, J. (2015). Green Signals: Ecology, Growth and Democracy in India (2015). Oxford: Oxford University Press. http://dx.doi.org/10.1093/acprof:oso/9780199457526.001.0001

Sachs, J. (2015). Sustainable Development for Humanity's Future. [Online] Available: http://jeffsachs.org/2015/08/sustainable-development-for-humanitys-future/

Stern, N. (2007). The Economics of Climate Change. Oxford: OUP. http://dx.doi.org/10.1017/CBO9780511817434

UN Framework Convention on Climate Change. [Online] Available: http://unfccc.int/ghg_data/ghg_data_unfccc/time_series_annex_i/items/3814.php

Wildavsky, A. (1987). Speaking Truth to Power. Piscataway: Transaction.

World Bank national accounts data. [Online] Available: data.worldbank.org

World Resources Institute CAIT Climate Data Explorer. [Online] Available: cait.wri.org

\section{Copyright Disclaimer}

Copyright for this article is retained by the author(s), with first publication rights granted to the journal.

This is an open-access article distributed under the terms and conditions of the Creative Commons Attribution license (http://creativecommons.org/licenses/by/3.0/). 